\title{
Susceptibility to weathering damage and oxidative stress on soybean seeds with different lignin contents in the seed coat $^{1}$
}

\author{
Caroline Huth ${ }^{2}$, Liliane Marcia Mertz-Henning ${ }^{3}$, Sidnei Jose Lopes ${ }^{2}$, \\ Luciane Almeri Tabaldi ${ }^{2}$, Liana Veronica Rossato ${ }^{2}$, \\ Francisco Carlos Krzyzanowski ${ }^{3}$, Fernando Augusto Henning ${ }^{3 *}$
}

\begin{abstract}
This study aimed at evaluating the relationship among lignin content in the seed coat of soybean seeds with tolerance to weathering damage and oxidative stress. Four soybean cultivars (CD 208, CD 215, CD 202 and BRS 184), with lignin contents in the seed coat of 4.2, 2.6, 2.0 and 1.7\%, respectively, were used. Seeds were subjected to deterioration by moisture, through artificially simulated rains. Pods of all cultivars were subjected to irrigation by constant sprinkling during 4 hours, and then dried in oven, set at $35^{\circ} \mathrm{C}$, for 37 hours; repeating twice such procedure. After these treatments seeds were subjected to tests and then compared to the control. Tests performed were: germination, accelerated aging and tetrazolium test; thereby quantifying the occurrence of damages by weathering damage. The activity of enzymes superoxide dismutase and guaiacol peroxidase was measured; and the lipid peroxidation was assessed. Soybean cultivars CD 208 and CD 215, with higher lignin content in the seed coat, were less susceptible to weathering damage. Seeds of cultivar CD 208 have also presented lower oxidative stress, when subjected to weathering damage stress.
\end{abstract}

Index terms: Glycine max. L, field deterioration, seed quality.

\section{Suscetibilidade à deterioração por umidade e ao estresse oxidativo em sementes de soja com variação no conteúdo de lignina no tegumento}

\begin{abstract}
RESUMO - O estudo teve como objetivo avaliar a relação entre o teor de lignina no tegumento de sementes de soja com tolerância à deterioração por umidade e ao estresse oxidativo. Foram utilizadas quatro cultivares de soja: CD 208, CD 215, CD 202 e BRS 184, com teores de lignina no tegumento de 4,2; 2,6;2,0 e 1,7\%, respectivamente. As sementes foram submetidas a uma deterioração por umidade através de chuvas simuladas (4 horas), e, posteriormente, secas em estufa $\left(35^{\circ} \mathrm{C}\right)$, por 37 horas, totalizando dois ciclos de umedecimento e secagem. Foram realizados os testes: germinação, envelhecimento acelerado e teste de tetrazólio. Foi medida a atividade das enzimas antioxidantes: Superóxido Dismutase e Guaiacol Peroxidase; e a peroxidação lipídica. As avaliações foram realizadas no delineamento inteiramente casualizado, em esquema fatorial 2x4, com quatro repetições. As cultivares de soja CD 208 e CD 215, com maior teor de lignina no tegumento, são menos suscetíveis ao dano por umidade. As sementes da cultivar CD 208 também apresentaram menor estresse oxidativo, quando submetidas a deterioração por umidade.
\end{abstract}

Termos para indexação: Glycine max. L, deterioração em campo, qualidade de sementes.

\section{Introduction}

The high productivity achieved on soybean [Glycine $\max (\mathrm{L}$.$) Merrill] fields are directly related to the success in$ the establishment of the plants on the field; what depends, among other factors, on utilization of high quality seeds. To be considered of high quality, the soybean seed must have physiological and health characteristics that provide high germination rates and vigor, as well as owning physical

${ }^{1}$ Submitted on 04/05/2016. Accepted for publication on 08/22/2016. ${ }^{2}$ Departamento de Fitotecnia, UFSM, 97105-900 - Santa Maria, RS, Brasil. and varietal purity assurance, and be free of impurities and contaminants (França-Neto et al., 2010).

Soybean seeds have a high susceptibility to environmental stresses, especially the occurrence of heavy rains, temperature fluctuations and relative humidity (RH) at pre-harvest; which are climatic conditions that may result on weathering damage (França-Neto et al., 2000; Costa et al., 2001; Cunha et al., 2009; Terasawa et al., 2009), thus impairing production of high quality seeds in some of the Brazilian seed production regions

${ }^{3}$ Embrapa Soja, Caixa Postal 231, 86001-970 - Londrina, PR, Brasil.

*Corresponding author < fernandohenning@yahoo.com.br > 
(Giurizatto et al., 2003). Moreover, according to data from the Brazilian National Supply Company (Conab), in the crop season of 2012/13 in the Brazilian Midwest region, the delay caused by the weather conditions at the beginning of soybean seeding, as well as occurrence of rainfalls coinciding with the harvest, promoted reductions of $3.8 \%$ and $5 \%$, respectively, on yield (CONAB, 2013). In the state of Paraná, Carraro and Peske (2005) found that the mean percentage of mechanical damages caused to the seed lots was above $10 \%$ and the damages caused by weathering damage were above $15 \%$.

The weathering damage is a result of soybean seed exposure to alternate cycles of high and low moisture before harvest, and is considered one of the main causes associated to reduced quality of the soybean seeds. Since these seeds are hygroscopic, and have their moisture content conditioned by the relative humidity conditions of environment, the successive expansions and contractions of their volume may lead to formation of wrinkles and cracks on the seed coat, as well as physical fatigue of the seed tissues, which may result on rupture of the seed coat.

Another consequence of the weathering damage on soybean seeds is the intensification of their respiratory process, which may cause oxidative stress; thus leading to formation of reactive oxygen species (ROS) and free radicals in the internal tissues of the seeds (Apel and Hirt, 2004). As a result of these disorders, the intracellular levels of ROS can quickly rise (Gill and Tuteja, 2010), depending on genotype, on intensity and duration of the stress, as well as of the seed developmental phase (Hameed et al., 2011). Furthermore, by acting directly on the cell membranes, free radicals, such as: superoxide $\left(\mathrm{O}_{2}^{-}\right)$, hydroxyl $(\mathrm{OH})$, hydrogen peroxide $\left(\mathrm{H}_{2} \mathrm{O}_{2}\right)$ and singlet oxygen $\left({ }^{1} \mathrm{O}_{2}{ }^{*}\right)$, can cause physiological changes on the seeds (Jaleel et al., 2007). These molecules can trigger a lipid peroxidation in the cell membranes; thus altering their fluidity and permeability (Ávila and Albrecht, 2010). The enzymes superoxide dismutase (SOD) and peroxidase (POD) are antioxidants and play a key role in the defense against the ROS (Simova-Stoilova et al., 2008).

The characteristics of soybean seed coat, such as semipermeability to water and high lignin content, can contribute to obtain seeds of good quality (Cavariani et al., 2009). It is in the seed coat that the lignin is present; being a natural polymer that varies in function of the genetic characteristics of cultivar, but that may also be influenced by the environment (Lewis and Yamamoto, 1990). Furthermore, the lignin is not only important to impart stiffness and resistance to plant tissues of the plant such as stems and leaves, but specifically to soy seed coat (Panobianco, 1999). According to FrançaNeto et al. (2007), the use of soybean genotypes with higher lignin content in the seed coat favors production of higher quality seeds. The lignin, besides increasing seed resistance to mechanical damages, has provided lower hydration speed to the seeds (Santos et al., 2007).

Although there are data and evidences indicating that the lignin content confers some resistance to weathering damage to the seeds, there are still missing more detailed data and methodologies that are similar to the adverse weather conditions, under which the seeds remain exposed in the field. Given this context, the aim of this study was to analyze the relationship between the lignin content in the seed coat of soybean seeds with tolerance to weathering damage and to oxidative stress.

\section{Material and Methods}

The soybean cultivars were selected from previous data obtained on the basis of routine analyzes performed in the Laboratory of Seed Technology and Grains of the Brazilian Agricultural Research Corporation, Embrapa Soja, located in Londrina, Paraná State, Brazil. From these data, the genotypes presenting the most distinguished behavior possible on lignin content in the seed coat were chosen; thereby selecting four soybean cultivars (CD 208, CD 215, CD 202 and BRS 184) with lignin content in the integument of, on average, 4.2, 2.6, 2.0 and $1.7 \%$, respectively.

Seeds were multiplied under controlled environmental conditions inside a greenhouse located at Embrapa Soja. To this, pots with $8 \mathrm{~L}$ capacity, all filled with a substrate composed of a mixture of soil: sand organic compound, in a proportion of 3:2:2, respectively, were used. Seeding was performed on July, $10^{\text {th }}, 2013$, to a depth of 3 to $5 \mathrm{~cm}$, after seed inoculation with Bradyrhizobium japonicum. Four seeds per pot were initially sown; and after emergence a thinning was performed, thus maintaining only two plants per pot. The greenhouse environmental conditions (temperature and relative humidity) were monitored with the equipment Instrutherm, model HP 500. For each cultivar 36 pots were used; thus totaling 72 plants per cultivar. The sprinkle irrigation was daily performed; and the cultural practices (application of insecticides and fungicides) were performed whenever needed necessary.

The pods from each cultivar were hand harvested only after the seeds had reached full maturity. Subsequently, the pods were sent to the Laboratory of Seed Technology and Grains of Embrapa Soja, where they were allowed to dry in a well ventilated environment. Soon after drying, the samples of each cultivar were then threshed separately and divided into three fractions: the first fraction was intended for the initial characterization of the seed physiological quality; the 
second fraction was used to determine the lignin content of the seed coat and resistance to mechanical damages; and the third fraction was used to determine the tolerance of the seeds to weathering damage.

\section{Initial characterization of seed quality:}

Germination test: was conducted according to procedures recommended by the Rules for Seed Testing (Brasil, 2009), and performed with four replications of 100 seeds each; and results were expressed in percentage of normal emerged seedlings.

Tetrazolium test: was conducted according to the methodology published by Moore (1985), and later described and improved by França-Neto et al. (1998), and carried out with 200 seeds per treatment; which were split into four subsamples, of 50 seeds each, and subsequently determining seed vigor, seed viability, percent of weathering damages and percent of mechanical damages.

Accelerated aging test: was conducted with four replications of 50 seeds for each cultivar, where clear plastic boxes (Gerbox type) were used; to which was added $40 \mathrm{~mL}$ of sterile distilled water, and on the upper edge of each box was placed a galvanized wire screen, on which seeds were evenly distributed. The boxes were then sealed with adhesive tape and taken to an incubator, set at $41^{\circ} \mathrm{C}$, for $48 \mathrm{~h}$, as described by Marcos-Filho (1999). After incubation, the seeds were subjected to the germination test, with four samples of 50 seeds each. Only a count of normal emerged seedlings was carried out on the fifth day.

\section{Determination of lignin content in the seed coat:}

Lignin content in the seed coat: the quantification of lignin was performed through the LTGA linothioglycolic acid method by using four replications of 20 seeds to each cultivar and each replication, which were first immersed in water for 12 hours. Following, the seeds coats were removed and dried at $105{ }^{\circ} \mathrm{C}$ for 16 hours. The obtained dried matter was crushed, homogenized and subjected to successive centrifugation (3300 rpm for four minutes) with different buffer solutions (sodium and potassium phosphate / Triton X-100 / 1.0 M $\mathrm{NaCl}$ / acetone), to obtain wall cell phone. Was performed by quantification of lignin LTGA method (linotioglicólico acid) (Capeleti et al., 2005).

Determination of the seed tolerance to weathering damage (WD):

Based on preliminary studies, tolerance of the seeds to the water stress was determined through simulated rains; which were obtained by 11 water sprinklers. A part of the seeds was stored in a cold and dry chamber (control) and the other part was subjected to the water stress. Four replications of 140 pods were used for each cultivar; which were harvested at the R8 reproductive stage (Fehr and Caviness, 1980). Immediately after harvest, the pods of each cultivar were then separately and evenly distributed on metallic screens and kept in a greenhouse under the 11 water sprinklers, thereby all the pods received a uniform irrigation. The irrigation was constant, for $4 \mathrm{~h}$, or until all pods had reached moisture content between $18 \%$ and $20 \%$. Subsequently, the pods were dried in a hot air circulating oven, set at $35^{\circ} \mathrm{C}$, for $37 \mathrm{~h}$. This cycle of wetting and drying was twice repeated; thus totaling two cycles of water stress. After these two cycles, the pods were manually threshed, and then the obtained seeds were subjected to tests and determinations; and results were compared to their respective controls without water stress.

Besides the germination and tetrazolium tests (previously described) it was also determined: the oxidative stress, which was obtained through the activity of the Guaiacol Peroxidase (POD) and Superoxide Dismutase (SOD) enzymes; as well as the content of peroxidation of lipids in the cell membranes, which was obtained by the Thiobarbituric Acid Reactive Substances (TBARS) assay.

Activity of POD and SOD enzymes: this assessment was performed with an individual sample of $0.5 \mathrm{~g}$ of seeds to each cultivar studied. Each sample was macerated and then homogenized in a $3 \mathrm{~mL}$ of $0.05 \mathrm{M}$ sodium phosphate buffer solution ( $\mathrm{pH} 7.8)$ containing $1 \mathrm{~m} \mathrm{M}$ of EDTA and $2 \%(\mathrm{w} / \mathrm{v})$ polyvinylpyrrolidone (PVP). The homogenate was centrifuged at $13,000 \times \mathrm{g}$ for $20 \mathrm{~min} .\left(4^{\circ} \mathrm{C}\right)$, and supernatant was used for determination of activity of the enzymes. The activity of the POD enzyme was determined by absorbance of the reaction solution, at $560 \mathrm{~nm}$, following the methodology described by Zeraik et al. (2008); whereas the SOD enzyme activity was determined at $480 \mathrm{~nm}$ (Mccord and Fridovich, 1969). Results were expressed as unit of enzyme per milligram protein (U.mg-1 protein). The protein content was determined according to Bradford (1976).

Peroxidation of membrane lipids (TBARS): it was assessed following the method described by El-Moshaty et al. (1993) and adapted for seeds. Samples of seeds of each cultivar were individually macerated in liquid nitrogen and homogenized in $20 \mathrm{~mL}$ of $0.2 \mathrm{M}$ citrate buffer ( $\mathrm{pH} 6.5$ ) containing $0.5 \%$ Triton $\mathrm{X}-100$. The homogenate was centrifuged for $15 \mathrm{~min}$. at 20,000 $\mathrm{x}$ g; and then $1 \mathrm{~mL}$ of supernatant was added to $1 \mathrm{~mL}$ of $20 \%$ TCA (w/v) containing $0.5 \%(\mathrm{w} / \mathrm{v})$ Thiobarbituric acid. The mixture was heated at $95{ }^{\circ} \mathrm{C}$ for 40 minutes and then cooled for 15 minutes, and centrifuged at $10,000 \mathrm{x}$ g for another 15 minutes. The absorbance of the supernatant was read at 532 and $600 \mathrm{~nm}$, to correct the non-specific turbidity; and lipid peroxidation was expressed as nmol MDA.mg-1 protein. 
All laboratory assays were performed in a completely randomized experimental design (CRD). For ANOVA of all tests, it was verified the compliance with the assumptions of the mathematical model, through the tests of normality of errors (Shapiro Wilks) and homogeneity of variances (Bartlett), by using the software Action. The assessments were performed in a completely randomized design, with the treatments arranged in a $2 \times 4$ factorial ( 2 simulated rains $\mathrm{x} 4$ cultivars), with four replications. The variables were subjected to ANOVA, at 5\% probability. Data were subjected to mean comparison by the Scott-Knott test through the Sisvar software (Ferreira, 2008). Presentation of results for the transformed variables was performed with original values.

\section{Results and Discussion}

The initial characterization of seed lots, in relation to the lignin content in the seed coat, proved to be fairly efficient on distinguishing among cultivars; since the cultivar CD 208 was the one presenting the highest lignin content $(4.2 \%)$ and cultivars CD 215, CD 202 and cultivar BRS 184 (2.6\%, 2.0\% and $1.7 \%$, respectively) presented the lowest lignin content in the seed coat (Table 1).

There was statistically significant difference for the variable weathering damages (WD); while for germination $(\mathrm{G})$ and accelerated aging (AA) there was no statistically significant differences among cultivars. The physiological quality of all cultivars was high (with G above 96\%) and the percentage of normal emerged seedlings was also high (above $88 \%$ ). In addition, any of the cultivars showed mechanical damages (MD) on the seed coat; thus demonstrating to be seed lots with high physiological quality (Table 1).

Even though the seeds have been produced under greenhouse environmental conditions, the range of variation between the maximum and minimum temperature was high, once the mean of minimum temperatures was of $16{ }^{\circ} \mathrm{C}$ and the mean of maximum temperatures was of $39.7{ }^{\circ} \mathrm{C}$; which may have contributed to the occurrence of WD on the seed coat of the seeds of the cultivars assessed. Thereby, the seeds of cultivars CD 208 and CD 215, with higher lignin content in the seed coat, have had a percentage of WD significantly lower, as compared to the seeds of cultivars CD 202 and BRS 184 with lower lignin content in the seed coat (Table 1).

Table 1. Initial characterization of seeds of four soybean cultivars with different percentages of lignin in the seed coat (LSC), and sorted by the percentage of normal emerged seedlings in the tests of germination $(\mathrm{G})$ and accelerated aging (AA), as well as by the percentages of weathering damages (WD) and mechanical damages (MD).

\begin{tabular}{cccccc}
\hline \multirow{2}{*}{ Cultivar } & \multicolumn{5}{c}{ Parameters assessed } \\
\cline { 2 - 6 } & LSC (\%) & G (\%) & AA (\%) & WD (\%) & MD (\%) \\
\hline CD 208 & 4.2 & $98 \mathrm{a}^{*}$ & $92 \mathrm{a}$ & $5 \mathrm{~b}$ & $0 \mathrm{a}$ \\
CD 215 & 2.6 & $99 \mathrm{a}$ & $97 \mathrm{a}$ & $7 \mathrm{~b}$ & $0 \mathrm{a}$ \\
CD 202 & 2.0 & $97 \mathrm{a}$ & $89 \mathrm{a}$ & $29 \mathrm{a}$ & $0 \mathrm{a}$ \\
BRS 184 & 1.7 & $98 \mathrm{a}$ & $93 \mathrm{a}$ & $24 \mathrm{a}$ & 0 \\
\hline Average & 2.6 & 98 & 93 & 16.13 & - \\
CV (\%) & - & 7.98 & 7.81 & 25.18 & $\mathrm{a}$ \\
\hline
\end{tabular}

*Means followed by the same lowercase letter, in the columns, do not statistically differ between each other, by the Scott-Knott test, at $5 \%$ probability.

Results obtained in the $\mathrm{G}$ test are in agreement with results obtained by Obando-Flor et al. (2004); who, in a study with three soybean cultivars (FT-2, FT-10 and IAC-2), reported that the cultivars FT-2 and FT-10, with higher lignin content in the seed coat $(6.19 \%$ and $5.28 \%$, respectively) showed a higher physiological potential.

In another study, using soybean cultivars with lignin contents in the seed coat ranging from 3\% to 5\%, Menezes et al. (2009) found a negative correlation between germination speed and lignin content, and reported that the higher the lignin content in the seed coat the shorter the time for seed germination. These same authors suggested that these results are consequence of a faster repair of membrane systems of the least deteriorated seeds (higher lignin content); thus leading to a faster seedling emergence. However, Carvalho et al. (2014) found that vigor of soybean seeds are independent of the lignin content in the seed coat; since the seeds of the soybean cultivars with higher lignin content in seed coat do not always show the best physiological quality.

The ANOVA for the variable $G$ showed that there was significant interaction between the variables cultivar $\mathrm{x}$ simulated rain, as well as were significant the individual effects for cultivar and simulated rain (Table 2). In the treatment in which the water stress was applied the cultivars with higher lignin content in seed coat (cv. CD 208 and cv.CD 215) showed a higher percentage of normal emerged 
seedlings in the test G; thus, statistically differing from the cultivars CD 202 and BRS 184. These two cultivars presented a significant reduction on $G$ when compared to the cultivar CD 202, which showed a higher reduction on the percentage of normal emerged seedlings (20\%) (Table 3).

However, in this study the variable WD did not show significant interaction between the factors cultivar and simulated rain (Table 2). Nevertheless, the effect of both factors alone was significant; i.e., the WD effect on the cultivars was independent of the treatments (with or without water stress). However, all cultivars had an increase in percentage of WD when subjected to the treatment with simulated rain (Table 3). Despite ANOVA had not shown significant interaction, the Scott-Knott test formed distinct groups of cultivars when in the presence or absence of WD; since the cultivar CD 208 was the one with the smallest increase on the percentage of WD (21\%), and the cultivar CD 202 was the one presenting the most significant increase (40\%) (Table 3$)$.

Table 2. Variance analysis (ANOVA) of germination $(\mathrm{G})$ and percentages of weathering damages (WD), seeds of four soybean cultivars, with differing amounts of lignin in the seed coat, subjected to two treatments, to water stress (WS) obtained through simulated rain, in relation to their respective controls (C) without water stress.

\begin{tabular}{cccrc}
\hline SV & \multicolumn{2}{c}{ G } & DS & DS \\
\cline { 2 - 5 } & DF & $833880984.62^{* *}$ & 1 & $6612.50^{* *}$ \\
Treat (A) & 1 & $301380955.46^{* *}$ & 3 & $1885.67^{* *}$ \\
Cultivars (B) & 3 & $195139877.24^{* *}$ & 3 & $131.50 \mathrm{~ns}$ \\
(A) X (B) & 3 & 7420407.79 & 24 & 59.00 \\
error & 56 & & 25.18 & \\
Total & 63 & & 30.50 \\
\hline CV (\%) & 7.98 & & \\
\hline Average & 34150.93 & &
\end{tabular}

ns: not significant indicate a $5 \%$ probability of error, by $\mathrm{F}$ test. $* *$ indicate significant at $5 \%$ probability of error, by $\mathrm{F}$ test.

Table 3. Percentages of germination $(\mathrm{G})$ and percentages of weathering damages (WD) obtained in seeds of four soybean cultivars, subjected to water stress (WS) obtained through simulated rain, in relation to their respective controls $(\mathrm{C})$ without water stress.

\begin{tabular}{|c|c|c|c|c|}
\hline \multirow{4}{*}{ Cultivar } & \multicolumn{4}{|c|}{ Parameters assessed } \\
\hline & \multicolumn{2}{|c|}{$\mathrm{G}(\%)$} & \multicolumn{2}{|c|}{ WD (\%) } \\
\hline & \multicolumn{4}{|c|}{ Treatments } \\
\hline & $\mathrm{C}$ & WS & $\mathrm{C}$ & WS \\
\hline CD 208 & $98 \mathrm{aA}$ & $97 \mathrm{aA}$ & $5 \mathrm{bB}$ & $26 \mathrm{aC}$ \\
\hline CD 215 & $99 \mathrm{aA}$ & $97 \mathrm{aA}$ & $7 \mathrm{bB}$ & $36 \mathrm{aC}$ \\
\hline CD 202 & $97 \mathrm{aA}$ & $77 \mathrm{bC}$ & $29 \mathrm{bA}$ & $69 \mathrm{aA}$ \\
\hline BRS 184 & $98 \mathrm{aA}$ & $85 \mathrm{bB}$ & $24 \mathrm{bA}$ & $50 \mathrm{aB}$ \\
\hline Average & 98 & 89 & 16 & 45 \\
\hline $\mathrm{CV} \%$ & \multicolumn{2}{|c|}{7.98} & \multicolumn{2}{|c|}{25.18} \\
\hline
\end{tabular}

*Means followed by the same lowercase letters in the lines and uppercase letters on the columns do not statistically differ between each other, by ScottKnott test, at $5 \%$ probability.

Such results indicate that seeds of cultivars with higher lignin content in the seed coat have lower permeability, which may be related to the thickness of the hourglass cell layer of the seed coat; which was not assessed in this study. However, the cultivars CD 202 and BRS 184, with lower lignin content in the seed coat, had a higher percentage of WD as compared to cultivars CD 208 and CD 215, with higher lignin content in the seed coat (Table 3).

Moreover, these results corroborate results obtained by Santos et al. (2007), in which were found positive results for the lignin content in the seed coat and in which the brown color showed higher lignin content in the seed coat; and in which they have also found that such characteristic has positively affected the physiological quality of the seeds and has provided lower hydration rate to the seeds.

In addition, the high percentages of WD, obtained with induction of seed deterioration through simulated rain, demonstrate that the methodology used within this study was able to reproduce climatic conditions similar to those occurring in the field. Thereby, results herein obtained do agree with results published by França-Neto et al. (2000; 2007), who asserted that the WD results from exposure of soybean seeds to alternate cycles of high and low moisture before harvest, and that such damage occurs due to occurrence of intermittent rains or daily fluctuations of the relative humidity, thus resulting in physical fatigue of the seed tissues; what may cause the rupture of the seed coat and of the embryonic tissues and that may explain the high percentages of WD identified in the tetrazolium test.

In relation to parameters related to the oxidative stress on the seeds, the POD enzyme presented significant effects 
for all the cultivars individually assessed, as well as for the interactions between the cultivars and water stress (WS) on the seeds (Table 4). However, for the cultivar CD 208, with higher lignin content in the seed coat, the activity of such enzyme was lower, whereas for the other cultivars assessed the activity of POD enzyme was higher, when seeds were subjected to the WS. Nevertheless, the seeds of cultivar CD 208 without WS, had higher activity of POD enzyme, in relation to the other cultivars. The cultivar BRS 184, with lower lignin content in seed coat, was the one presenting the largest increase on the activity of such enzyme, after the WS (Table 5).

Table 4. Variance analysis (ANOVA) of Enzymes guaiacol peroxidase (POD) and superoxide dismutase (SOD), and lipid peroxidation (TBARS), seeds of four soybean cultivars, with differing amounts of lignin in the seed coat, subjected to two treatments, to water stress (WS) obtained through simulated rain, in relation to their respective controls (C) without water stress.

\begin{tabular}{crcrccc}
\hline \multirow{2}{*}{ SV } & \multicolumn{2}{c}{ SOD } & \multicolumn{3}{c}{ POD } & \multicolumn{2}{c}{ TBARS } \\
\cline { 2 - 7 } & DF & MS & DF & MS & DF & $0.007^{* *}$ \\
\hline Treat (A) & 1 & $2.142 \mathrm{~ns}$ & 1 & $0.073^{* *}$ & 1 & 3 \\
Cultivars (B) & 3 & $76.026^{* *}$ & 3 & $0.008^{* *}$ & 3 & $0.004 \mathrm{~ns}$ \\
(A) X (B) & 3 & $80.114^{* *}$ & 3 & 0.000 & 24 & $0.006 \mathrm{~ns}$ \\
error & 16 & 3.690 & 16 & & 31 & 0.0004 \\
Total & 23 & & 23 & & 33.47 & 0.18 \\
CV (\%) & 11.75 & & 5.98 & & \\
Average & 16.35 & & 0.14 & & & \\
\hline
\end{tabular}

ns: not significant indicate a $5 \%$ probability of error, by $\mathrm{F}$ test. ** indicate significant at 5\% probability of error, by $\mathrm{F}$ test.

Table 5. Activity of Enzymes guaiacol peroxidase (POD) and superoxide dismutase (SOD), as well as lipid peroxidation (TBARS) assessed in the seeds of four different soybean cultivars originated from seeds with dissimilar lignin content in seed coat and subjected to water stress (WS), in relation to their respective controls (C).

\begin{tabular}{|c|c|c|c|c|c|c|}
\hline \multirow{4}{*}{ Cultivar } & \multicolumn{6}{|c|}{ Enzime/Method } \\
\hline & \multicolumn{2}{|c|}{ POD $^{1}$} & \multicolumn{2}{|c|}{$\mathrm{SOD}^{1}$} & \multicolumn{2}{|c|}{ TBARS TEST $^{2}$} \\
\hline & \multicolumn{6}{|c|}{ Treatments } \\
\hline & $\mathrm{C}^{3}$ & $\mathrm{WS}^{4}$ & $\mathrm{C}$ & WS & $\mathrm{C}$ & WS \\
\hline CD 208 & $0.30 \mathrm{aA}$ & $0.24 \mathrm{bA}$ & $5.68 \mathrm{aA}$ & $4.66 \mathrm{bB}$ & 0.15 & 0.15 \\
\hline CD 215 & $0.17 \mathrm{bB}$ & $0.21 \mathrm{aB}$ & $4.75 \mathrm{bB}$ & $5.20 \mathrm{aA}$ & 0.16 & 0.22 \\
\hline CD 202 & $0.004 \mathrm{bC}$ & $0.08 \mathrm{aD}$ & $3.54 \mathrm{bC}$ & $4.70 \mathrm{aB}$ & 0.15 & 0.20 \\
\hline BRS 184 & $0.008 \mathrm{bC}$ & $0.10 \mathrm{aC}$ & $4.65 \mathrm{aB}$ & $4.65 \mathrm{aB}$ & 0.13 & 0.27 \\
\hline Average & 0.12 & 0.16 & 4.65 & 4.80 & $0.15 \mathrm{~b}$ & $0.21 \mathrm{a}$ \\
\hline $\mathrm{CV} \%$ & \multicolumn{2}{|c|}{5.98} & \multicolumn{2}{|c|}{5.41} & \multicolumn{2}{|c|}{33.47} \\
\hline
\end{tabular}

*Means followed by the same lowercase letters in the lines, in each enzyme system, and uppercase letters on the columns do not statistically differ between each other, by Scott-Knott test, at 5\% probability. ${ }^{1}$ enzyme activity expressed in U.mg ${ }^{-1}$ protein; ${ }^{2}$ lipid peroxidation expressed in nmol MDA.mg ${ }^{-1}$ protein; ${ }^{3} \mathrm{C}$ $=$ control (seeds without water stress); ${ }^{4} \mathrm{WS}=$ seeds with water stress induced by simulated rain.

The ANOVA performed with data obtained for the effects of SOD enzyme on the seeds showed significance to the cultivars individually and cultivate interaction and WD; however, the effect of WD were not significant (Table 4). The seeds of cultivar CD 208 presented decrease in the SOD enzyme activity when subjected to stress by WD; and the seeds of cultivars CD 215 and CD 202, with content of lignin in seed coat $2.6 \%$ and $2.0 \%$, respectively, had significant increase for such enzyme, as compared to their respective controls. However, the seeds of cultivar BRS 184, with lower lignin content in seed coat, did not significantly differ between the two treatments assessed (Table 5).

The ANOVA of means obtained for lipid peroxidation, measured by the TBARS test, showed significant effect only for the treatment without stress by WD (control); i.e., almost all cultivars with or without WD on the seeds, individually, did not show statistically significant differences between each other, regardless of the lignin content in the seed coat (Table 4). However, in the control treatment, only the seeds of cultivar BRS 184, with lower lignin content in seed coat, 
showed statistically significant difference with the increase of the lipid peroxidation on the seeds when subjected to stress by WD (Table 5 ).

As for the evaluation of oxidative enzymes, Senaratna and McKersie (1986), who, in a study with embryonic axes of soybean seeds, stated that SOD enzyme is the most notable example of neutralizing agent of free radicals, as it is effective even at the least signal of WD. However, Rosa et al. (2005), who, working with tolerance of maize seeds to the stresses caused by high drying temperatures, found no statistically significant difference in the SOD enzyme activity on the seeds.

Within the analysis of lipid peroxidation, the collapse of the cell membranes was always considered as the first degenerative event of seeds; however, currently, it is accepted that the molecular and biochemical damages occur before this event, and that evaluations of enzymatic activity, in the seeds with stress by $\mathrm{WD}$, is one of the most sensitive methods to detect them.

In addition, the literature on the subject cites: a) that the mitochondrial respiratory chain is a major source of ROS, and that the escape of electrons of the transport chain generates superoxide $\left(\mathrm{O}_{2}^{-}\right)$and subsequently hydrogen peroxide $\left(\mathrm{H}_{2} \mathrm{O}_{2}\right)$ via dismutation (Moller, 2001); b) that under normal conditions, about $2 \%$ to $3 \%$ of the oxygen used by the mitochondria can be converted to $\mathrm{O}_{2}{ }^{-}$and $\mathrm{H}_{2} \mathrm{O}_{2}$ (Chance et al., 1973; Puntarulo et al., 1988); and c) that the amount of $\mathrm{H}_{2} \mathrm{O}_{2}$ produced is directly proportional to the respiratory activity (Staniek and Nohl, 2000). Thereby, the orthodox seeds have intense respiratory rates during the early stages of embryonic development; however, these respiratory rates decrease during the drying phase on the mother plant, and become null when the seeds are dormant (Bewley and Black, 1994). It is estimated that mitochondrial respiration ceases with a water content of less than $0.25 \mathrm{~g}$ dry weight (Vertucci and Farrant, 1995). As germination is associated to the sharp increase in the respiratory activity and to the production of ROS, the seeds need of an efficient control by antioxidant mechanisms, so that lipid peroxidation does not occur; what was demonstrated in the treatments assessed within this study, since the activity of the enzymes POD and SOD were higher, when the soybean seeds were subjected twice to treatments with simulated rainfall and subsequent drying. The seeds of cultivars with higher lignin content in the seed coat showed lower activity of POD and SOD enzymes, in relation to cultivars with lower lignin content in the seed coat (Table 5), i.e., the higher was the lignin content in the seed coat of the seeds of cultivars assessed, lower was the oxidative stress generated and lower was the activity of these enzymes; what agrees with the results obtained by Bailly (2004), who affirms that other protection mechanisms should not be discarded, and that antioxidant enzymes should be considered as an important part of a broader arsenal of protection against the stress caused by water losses.

\section{Conclusions}

The seeds of soybean cultivars CD 208 and CD 215, with lignin content in the integument of $4.2 \%$ and $2.6 \%$, respectively, are less susceptible to the weathering damages induced by water stress.

When subjected to the water stress, the seeds of the CD 208 soybean cultivar presented less oxidative stress and lower percentage of weathering damages, apparently due to the higher content of lignin in the seed coat $(4.2 \%)$, to the low activity of the POD and SOD enzymes, and low lipid peroxidation.

\section{Acknowledgements}

The Brazilian Agricultural Research Corporation, Embrapa Soja, and the Federal University of Santa Maria for the great support and assistance in this research.

\section{References}

APEL, K.; HIRT, H. Reactive oxygen species: metabolism, oxidative stress, and signal transduction. Annual Review of Plant Biology, v.55, p.373-399, 2004. http://www.annualreviews.org/doi/full/10.1146/ annurev.arplant.55.031903.141701?url ver=Z39.88-2003\&rfr $\mathrm{id}=$ ori $\% 3$ Arid $\% 3$ Acrossref.org\&rfr_dat $=$ cr_pub\%3Dpubmed\&

ÁVILA, M. R.; ALBRECHT, L. P. Isoflavonas e a qualidade das sementes de soja. Informativo ABRATES, v.20, n.1, p.15-29, 2010. http://www.abrates. org.br/images/stories/informativos/v20n12/artigo02.pdf

BAILLY, C. Active oxygen species and antioxidants in seed biology. Seed Science Research, v.14, p. 93-107, 2004. http://www. scielo.br/scielo.php? script $=$ sci_nlinks\&ref $=000067 \& \mathrm{pid}=\mathrm{S} 0101$ 3122201000010001000005\&lng=pt

BEWLEY, J. D.; BLACK, M. Seeds: Physiology of development and germination. 2ed.PlenumPress, NewYork, 445p. 1994.http://www.scielo.br/scielo.php?script=sci nlinks\&ref $=000078 \&$ pid $=$ S01039016200900030001700002\&lng=en

BRADFORD, M. M. A rapid and sensitive method for the quantitation of microgram quantities of protein utilizing the principle of protein-dye binding. Analytical Biochemistry, v.72, p.248-254, 1976.

BRASIL. Ministério da Agricultura, Pecuária e Abastecimento. Regras para análise de sementes. Ministério da Agricultura, Pecuária e Abastecimento. Secretaria de Defesa Agropecuária. Brasília: MAPA-ACS, 2009. 395p. http:// www.agricultura.gov.br/arq_editor/file/2946_regras_analise_sementes.pdf

CAPELETI, I.; FERRARESE, M. L. L.; KRZYZANOWSKI, F. C.; FERRARESE FILHO, O. A new procedure for quantification of lignin in soybean (Glycine $\max$ (L.) Merrill) seed coat and their relationship with the resistance to mechanical damage. Seed Science and Technology, v.33, p.511-515, 2005.http://www.scielo.br/scielo.php?script=sci nlinks\&ref $=000084 \&$ pid $=$ S1413-7054201000020001500006\&lng $=$ pt 
CARRARO, I. M.; PESKE, S. T. Uso de sementes de soja no estado do Paraná. Revista Brasileira de Sementes, v. 27, p. 75-80, 2005. http://www. scielo.br/pdf/rbs/v27n2/a11v27n2.pdf

CARVALHO, E. R.; OLIVEIRA, J. A.; CALDEIRA, C. M. Qualidade fisiológica de sementes de soja convencional e transgênica RR produzidas sob aplicação foliar de manganês. Bragantia, v.73, n. 3, p.219-228, 2014. www.scielo.br/pdf/brag/v73n3/aop_brag_0096_pt.pdf

CAVARIANI, C.; TOLEDO, M. Z.; RODELLA, R. A.; FRANÇA-NETO, J. B.; NAKAGAWA, J. Velocidade de hidratação em função de características do tegumento de sementes de soja de diferentes cultivares e localidades. Revista Brasileira de Sementes, v.31, n.1, p.31-39, 2009. http://www.scielo. br/scielo.php?script=sci_arttext\&pid=S0101-31222009000100004

CHANCE, B.; BOVERIS, A.; OSHINO, N.; LOSCHEN, G. The nature of catalase intermediate and its biological function. In: KING, T.E.; MASON, H.S.; MORRISON, M. Oxidases and related redox systems, 1973. p. 350-353.

CONAB - Companhia Nacional de Abastecimento. Acompanhamento da safra brasileira: grãos, quarto levantamento, janeiro de 2013. <http://www. conab.gov.br/OlalaCMS/uploads/arquivos/15_01_09_09_00_21_boletim graos_janeiro_2015.pdf $>$ Accessed on: Jan. $28^{\text {th }}, 2015$.

COSTA, N. P.; MESQUITA, C. M.; MAURINA, A. C.; FRANÇA-NETO, J. B.; PEREIRA, J. E.; BORDINGNON, J. R.; KRZYZANOWSKI, F. C.; HENNING, A. A. Efeito da colheita mecânica da soja nas características físicas, fisiológicas e químicas das sementes em três estados do Brasil. Revista Brasileira de Sementes, v.23, p.140-145, 2001. http://www. scielo.br/scielo.php? script $=$ sci_nlinks \& ref $=000070 \&$ pid $=$ S0101$3122200300010002000007 \& \operatorname{lng}=$ en

CUNHA, J. P. A. R.; OLIVEIRA, P.; SANTOS, C. M.; MION, R. L. Qualidade das sementes de soja após a colheita com dois tipos de colhedora e dois períodos de armazenamento. Ciência Rural, v.39, n.5, p.1420-1425, 2009. http:// www.scielo.br/scielo.php?script=sci_nlinks\&ref=000085\&pid=S2317$1537201300030001200007 \& \operatorname{lng}=\mathrm{pt}$

EL-MOSHATY, F.I.B.; PIKE, S.M.; NOVACKY, A.J.; SEHGAL, O.P. Lipid peroxidation and superoxide productions in cowpea (Vigna unguicultata) leaves infected with tobacco rings virus or southern bean mosaic virus. Journal Physiological and Molecular Plant Pathology, v.43, p.109-119, 1993.

FEHR, W. R., CAVINESS, C. E. Stages of soybean development. Special Report 80,12p. Cooperative Extension Service, Iowa State University, Ames, Iowa, 1980.

FERREIRA, D.F. SISVAR: um programa para análises estatísticas e ensino de estatística. Revista Symposium, v.6, p.36-41, 2008. http://www.scielo.br/scielo.php?script=sci_ nlinks\&ref $=000096 \&$ pid $=$ S0 $1002945201200020003400006 \& \operatorname{lng}=$ es

FRANÇA- NETO, J. B.; HENNING, A. A.; KRZYZANOWSKI, F. C.; COSTA, N. P. Tecnologia de produção de sementes. In: A CULTURA DA SOJA NO BRASIL. CD-Rom, EMBRAPA-CNPSo, Londrina, 2000.

FRANÇA- NETO, J. B.; KRYZANOWSKI, F. C.; SILVA, W. R. O teste de tetrazólio em sementes de soja. Documentos 116, 72 p. EMBRAPA-CNPSo, Londrina, 1998.

FRANÇA-NETO, J. B.; KRZYZANOWSKI, F. C.; HENNING, A. A. A importância do uso de sementes de soja de alta qualidade. Informativo ABRATES, v. 20, n.1, p. 37-38, 2010.

FRANÇA- NETO, J. B.; KRZYZANOWSKI, F. C.; PÁDUA, G. P.; COSTA, N. P.; HENNING, A. A. Tecnologia da produção de sementes de soja de alta qualidade. EMBRAPA - CNPSo, Circular técnica 40, 12 p., 2007.
GILL, S.S.; TUTEJA, N. Reactive oxygen species and antioxidant machinery in abiotic stress tolerance in crop plants. Plant Physiology and Biochemistry, v.48, p.909-930, 2010. http://www.scielo.br/scielo.php?script=sci_ nlinks\&ref $=000089 \&$ pid $=$ S18066690201100020002000016\&lng=pt

GIURIZATTO, M. I. K.; SOUZA, L. C. F.; ROBAINA, A. D.; GONÇALVES, M. C. Efeito da época de colheita e da espessura do tegumento sobre a viabilidade e o vigor de semente de soja. Ciência e Agrotecnologia, v.27, n.4, p.771-779, 2003. http://www.scielo.br/scielo.php?script=sci pdf\&pid $=$ s141370542003000400005\&lng=en\&nrm=iso\&tlng $=$ pt

HAMEED, A.; BIBI, N.; AKHTER, J.; IQBAL, N. Differential changes in antioxidants, proteases, and lipid peroxidation in flag leaves of wheat genotypes under different levels of water deficit conditions. Plant Physiology and Biochemistry, v.49, p.178-185, 2011. 10.1016/j. plaphy.2010.11.009 PubMed: 21159517 [PubMed]

JALEEL, C. A.; MANIVANNAN, P.; SANKAR, B.; KISHOREKUMAR, A.; GOPI, R.; SOMASUNDARUM, R.; PANNEERSELVAN, R. Water deficit stress mitigation by calcium chloride in Catharanthus roseus: Effects on oxidative stress, praline metabolism and indole alkaloid accumulation. Colloids and Surfaces B. Biointerfaces, v.60, p.110-116, 2007. http://www. ncbi.nlm.nih.gov/pubmed/17643271 [PubMed]

LEWIS, N. G.; YAMAMOTO, E. Lignin: occurrence, biogenesis and biodegradation. Annual Review Plant Physiology and Plant Molecular Biology, v.41, p. 455-496, 1990.

MARCOS-FILHO, J. Teste de envelhecimento acelerado. In: KRZYZANOWSKI, F.C.; VIEIRA, R.D.; FRANÇA-NETO, J.B. (Ed.) Vigor de sementes: conceitos e testes. 1999. p.1-24.

MCCORD, J. M.; FRIDOVICH, I. Superoxide dismutase: an enzymic function for erythrocuprein (hemocuprein). Journal of Biological Chemistry, v. 244 , p.6049-6055, 1969

MENEZES, M.; PINHO, E. V. R V.; ROVERI JOSÉ, S. C. B.; BALDONI, A.; MENDES, F. F. Aspectos químicos e estruturais da qualidade fisiológica de sementes de soja. Pesquisa Agropecuária Brasileira, v.44, n.12, p.17161723, 2009. http://seer.sct.embrapa.br/index.php/pab/article/view/1464

MOLLER, I. M. Plant mitochondria and oxidative stress:electron transport, NADPH turnover, and metabolism of reactive oxygen species. Annual Review of Plant Physiology and Plant Molecular Biology, v.52, p.561-591, 2001. http://www.scielo.br/scielo.php?script=sci nlinks\&ref $=000137 \&$ pid $=$ S1415-4366201100040001400029\&lng $=\mathrm{pt}$

MOORE, R. P. Handbook on tetrazolium testing. International Seed Testing Association, 1985. 99p.

OBANDO-FLOR, E. P.; CICERO, S. M.; FRANÇA-NETO, J. B.; KRZYZANOWSKI, F. C. Avaliação de danos mecânicos em sementes de soja por meio da analise de imagem. Revista Brasileira de Sementes, v.26, n.1, p. 68-76, 2004. http://www.scielo.br/pdf/rbs/v26n1/a11v26n1.pdf

PANOBIANCO, M. Electrical conductivity of soybean seed and correlation with seed coat lignin content. Seed Science Technology, v. 27, n. 3, p. 945$949,1999$.

PUNTARULO, S.; SANCHEZ, R. A.; BOVERIS, A. Hydrogen peroxide metabolism in soybean embryonic axes at the onset of germination. Plant Physiology, v.86, p.626-630, 1988. http://www.ncbi.nlm.nih.gov/pmc/ articles/PMC1054535/ 
ROSA, S. D. V. F.; VON PINHO, E. V. R.; VIEIRA, E. S. N.; VEIGA, R. D.; VEIGA, A. D. Enzimas removedoras de radicais livres e proteínas lea associadas à tolerância de sementes de milho à alta temperatura de secagem. Revista Brasileira de Sementes, v. 27, n. 2, p. 91-101, 2005. http://www. scielo.br/scielo.php?script=sci_arttext\&pid=S0101-31222005000200014

SANTOS, E. L.; PÓlA, J. N.; BARROS, A. S. R.; PRETE, C. E. C. Qualidade fisiológica e composição química das sementes de soja com variação na cor do tegumento. Revista Brasileira de Sementes, v.29, n.1, p. 20-26, 2007. http://www.scielo.br/scielo.php?script=sci arttext\&pid=S0101-31222007000100003

SENARATNA, T.; MCKERSIE, B. D. Loss of desiccation tolerance during seed germination: a free radical mechanism of injury. In: LEOPOLD, A. C. Membranes, metabolism and dry organisms, p.85-101, 1986.

SIMOVA-STOILOVA, L.; DEMIREVSKA; K.; PETROVA, T.; TSENOV, N.; FELLER, U. Antioxidative protection in wheat varieties under severe recoverable drought at seedling stage. Plant Soil Environmental, v.54, p.529-536, 2008. https://www.researchgate.net/profile/Nikolay_Tsenov2/ publication/234064969 Antioxidative protection in wheat varieties under_severe_recoverable_drought_at_seedling_stage._Plant_Soil_Environ/ links/02bfe50ec6de86d9fe $000000 . p d f$
STANIEK, K.; NOHL, H. Are mitochondria a permanent source of reactive oxygen species? Biochimica et Biophysica Acta, v.1460, p.268-275, 2000 http://www.sciencedirect.com/science/article/pii/S0005272800001523

TERASAWA, J. M.; PANOBIANCO, M.; POSSAMAI, E.; KOEHLER, H. S. Antecipação da colheita na qualidade fisiológica de sementes de soja. Bragantia, v.68, n.3, p. 65-773, 2009. http://www.scielo.br/scielo. php?script=sci_arttext\&pid=S0006-87052009000300025

VERTUCCI, C. W.; FARRANT, J. M. Acquisition and loss of desiccation tolerance. In: KIGEL, J.; GALILI, G. Seed development and germination. p. 237-271, 1995.

ZERAIK, A. E.; SOUZA, F. S.; FATIBELLO-FILHO, O.; LEITE, O. D. Desenvolvimento de um spot test para o monitoramento da atividade da peroxidase em um procedimento de purificação. Química Nova, v.31, p. 731-734, 2008. http://www.scielo.br/scielo.php?script=sci arttext\&pid=S0100-40422008000400003 